\title{
Dynamics of Corporate Startup Collaboration: An Exploratory Study
}

\author{
HONG YUH CHING \\ CENTRO UNIVERSITÁRIO DA FEI, Brazil \\ Rebeca Moreno Caetano \\ CENTRO UNIVERSITÁRIO DA FEI, Brazil
}

Received: Jan. 19, $2021 \quad$ Accepted: April 7, $2020 \quad$ Published: April 7, 2021

doi:10.5296/jmr.v13i2.18217 URL: https://doi.org/10.5296/jmr.v13i2.18217

\begin{abstract}
Drawing on two datasets of companies, this paper investigates the underlying dynamics of corporate startup collaboration (CSC) in Brazil as well as the reasons why corporations engage with startup and vice versa. The authors have used several types of collaboration found in the literature and the reasons of collaboration, as the basis to support the research. It suggests that the search for a line of radical innovation and collaboration strategy and also be part of an ecosystem are associated with the significant increase in two years in number of companies, programs, and engagement, resembling international data on the subject. This search for innovation and collaboration strategy and be part of an ecosystem are likely to be driven by three industry sectors that most stand out. Matchmaking, Training \& Mentoring and Pilot Project Contracting were the top three types of engagement. They are seen as partnership between corporation and startup, where both sides can learn and grow in this process, rather than an one-off transaction. The results offer insights into the emerging trend of corporate startup collaboration, especially companies and startups, that are not yet engaged with each other, can take results as a basis to start engaging and/or create a line of innovation and engagement strategy by understanding the nature of engagement and its programs. This study also shed lights on Brazilian startups and their collaboration with incumbents (local and international) as well as on industry sectors that most standout.
\end{abstract}

Keywords: Disruptive Innovation, Corporate collaboration, Startups, Corporate engagement. 


\section{Introduction}

Much is discussed about the differences and problems of relationship between corporations and startups. Yu \& Hang (2010) state there is a general asymmetry between them. While the startups have a risky and uncertain environment, longing for growth, the corporations have resources, credibility, and a more stable environment, despite facing challenges such as inflexible culture and focus on incremental innovation. This asymmetry, like differences in power, structure, and decision-making, makes beneficial connections hard to achieve for both parties (Prashantham \& Kumar, 2019). The corporation has the resources, scale, and all processes necessary for the business model to function efficiently. The startup often has promising ideas, organizational agility, a willingness to risk, and a fast-growing ambition. Each side has what the other does not have, however the difference between cultures makes the approach of companies complicated (Weiblen \& Chesbrough, 2015).

Understanding the changing dynamics is crucial for both startups and corporations to gain from this trend and to innovate together. Ultimately, the key to a successful startup/corporate partnership is to see it as just that, a partnership, rather than a quick one-off transaction. Often there is a lot more to be learned and developed together and both sides can learn and grow in the process (Imaginaik and Masschallenge, 2016). Thieme (2017) argues that startups are no longer perceived as a threat by the corporation but as potential partners being this engagement an important part of their innovation strategy.

According to Bonzom \& Netessine (2016), 68 pct. of companies listed at Forbes Global 500 (https://fortune.com/global500/2015/) are engaging with startups and over $50 \%$ of the unicorns mentioned by Wall Street Journal (https://www.wsj.com/graphics/billion-dollar-club/) have some kind of relationship with at least one company.

In Brazil, according to ABStartups (https://startupbase.com.br/home/stats), in 2019 there were around 12000 startups registered, doubled from 2018. In 2020, the company 100 Open Startups mapped that 1.635 corporations were engaged in some kind of relationship with startups through their platform, there has also been an exponential growth in the number of relationships: 20 times in the last 5 years (100 OpenStartups, 2020). It has been clear that not only there was an increase in the number of startups in Brazil but also in engagements between corporations and startups.

Collaboration between corporates and startups is a challenge for the mind-sets on both sides. Corporate employees are trained to follow standardized processes and are challenged by the creative behavior of entrepreneurs. Many entrepreneurs start their companies with the intention of disrupting the status quo and are challenged by the idea of working with the players they set out to topple (World Economic Forum WEF, 2018).

For Thieme (2017), the focus on incremental innovation is also one of the reasons why 
companies fail to innovate radically as they prefer to focus on improving existing products with their structured business model targeted to known audience and to increase the profits of these technologies already explored. Usually, corporations have bureaucratic processes and structures, and, with more formalities, innovation tends to slow down.

The objectives of this article are: investigate the underlying dynamics of corporate startup collaboration (CSC) in Brazil as well as the reasons why corporations engage with startup and vice versa. To help understand the dynamics, the results will display the business sectors that most engage with startups, the types, and quantities of collaborations and which of them had the highest growth.

While the concepts of disruptive and open innovation are well researched (see specific section below), corporate startup collaboration models and typologies, i.e., the various ways in which corporations collaborate with startups for innovation, is not yet well researched. This perception is also shared by Hogenhuis, Van den Hende \& Hultink (2017). In Brazil, the scenario is even worse with scarce literature (100 open startups, 2017; Grando, 2016). This study is unprecedented by shedding more light on Brazilian startups and their collaboration with incumbents (local and international) as well as on industry sectors that most standout in collaborations/engagements. Both (startup and companies) can take results as a basis to start engaging and/or create a line of innovation and engagement strategy by understanding the nature of engagement and its programs. It can also be used by companies that are not yet engaged with startups to have an insight into how to engage and what other companies are doing in Brazil and elsewhere in the world.

The sections below start with a theoretical context, the methodology applied in this study followed by results and discussion and the conclusions.

\section{Literature Review}

The following topics below are discussed so that the dynamics of corporate collaboration can be better contextualized, such as disruptive and open innovation and startups and their ecosystem, correlated studies on corporate startup collaboration and the reasons why companies collaborate with startups and vice-versa and finally the types or models of collaboration that corporations have with startups.

\subsection{Open and Disruptive Innovation}

Corporations have used open innovation to enhance radical and disruptive innovation by searching partners (Pénin et al. 2011). The model (figure 1), as introduced by Chesbrough et al. (2006), uses internal and external ideas and knowledge to speed the internal innovation and expand the markets to the external use of innovation. It shows that innovation comes from internal and external technology basis where the resulting projects can be launched in the market, licensed to other parties and/or can origin a spin-off into a new market (Chesbrough et al. 2006). 


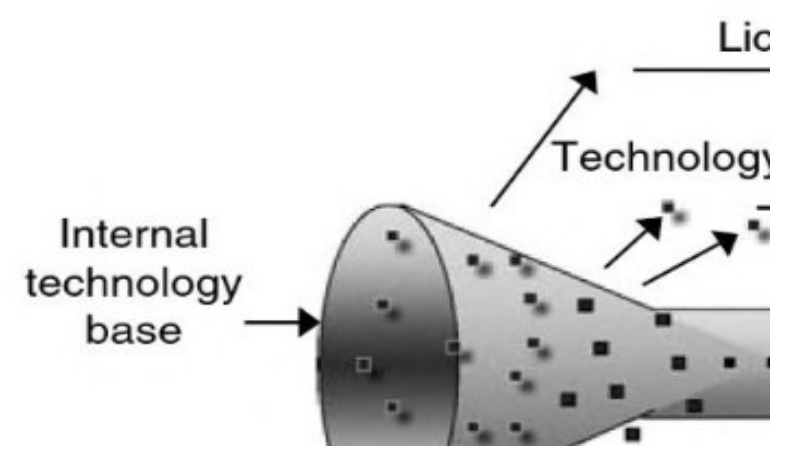

Figure 1. Open innovation model

For Chesbrough et al. (2006), Bonzom \& Netessine (2016) and Christensen (1997), open innovation is an alternative for companies to stay tuned to new market trends and protect themselves from disruptive innovation and loss of market share. On the other hand, closed innovation model is based on the concept that all innovations are developed internally by the R\&D sector, where the approved projects are launched to a previously determined market. Entrants that prove disruptive begin by targeting those overlooked segments, gaining a foothold by delivering more sustainable functionality at a lower price (Christensen et al, 2015). Technological innovation can be separated in two types - the incremental and the disruptive:

Known as "sustaining innovation", the most common is the incremental, where the company improves a technology to develop existing markets, thus creating more value to the consumer (Charles, 2016). An example is the smartphone manufacturers that develop devices faster and with more features to users. This type of innovation is financially attractive by meeting well established markets and clients (Yu \& Hang, 2010).

The second type, the disruptive, is the one that creates new markets with new value propositions to clients and values networks. This latter means that value is provided to people that were not consumers before, who could not afford the product or who appreciate new values that the product brings (Charles, 2016). For Charles (2016) and Christensen et al., (2015), disruptive innovation gets started in two types of markets that incumbents overlook:

Low-end disruption: innovation that begins by supplying the needs of a different group that corporation's value and feel overserved by them. Companies with low-end disruption do not create products, instead create new business models that are able to lower cost and consequently offer cheaper products.

New-market disruptors: innovations that create a whole new market by focusing on consumer characteristics and providing something they want or need that was not perceived before.

Corporations can use startups' speed of operation as inspiration for their own operations, 
looking for a less bureaucratic company. In addition to inspiration, large companies can also use startups' solutions to make their business model more agile and offer more value to consumers, making their business model more innovative (Thieme, 2017).

\subsection{Startups and their ecosystem}

For this work, the definition of Startup is used as being a company, a partnership, a temporary organization, or even new divisions in a company (and/or nonprofit organization), designed to search for a repetitive and scalable business model and/or develops new products and services under conditions of extreme uncertainty, considering only essential processes for their operation. (Blank, 2010, Ries, 2012 and Linna Jr., 2016).

Corporates are not alone in their endeavor to work more closely with startups. There is today a wider support ecosystem developing in Europe, where a range of organizations serves as platforms to facilitate collaborations between corporates and startups. Among them other companies, accelerators, universities, institutional investors, and policymakers, with whom corporates can partner for support and guidance. Such partnerships bring various benefits: the right partners have the expertise and experience to design programs appropriate for your company's goals and priorities. Good ecosystem partners will understand both the corporate and startup worlds and corporate-startup collaboration can also be a way to take part in the construction of new entrepreneurial ecosystems (Mocker, Bielll \& Halley, 2015, Bonzom \& Netessine, 2016 and Drori \& Wright, 2018)

Some questions that startups should keep in mind about the ecosystem is where it could create its startup to maximize the chances of success and which ecosystem is the best for the sector that your startup will fit into. Investors should also check which ecosystem has the best performance in the sector they are focusing on and which ecosystem has a gap in which the investor could enter. Policymakers can change local policies to support the startup ecosystem, can research what are the biggest gaps in it that they could focus on first and how to measure ecosystem progress (Startup Genome, 2019).

\subsection{Correlated studies on corporate startup collaboration}

Steiber (2020) investigated a corporate startups collaboration model as an organizational innovation and using an established framework for the diffusion of innovations on a case study. The three sets of factors (external factors, internal factors, and the characteristics of the organizational innovation itself) were proved to influence the diffusion of the collaboration model called "FirstBuild".

Ghobril, Franklin, Gava, Libano, Silva \& Zinger (2019) investigated how the cooperative relationship between startups and organizations occurs to meet demands for technological innovation. The research showed the relevance of the performance and mediation of the accelerators which, when making the marriage between the two parties, seek to show organizations how the startup can help them grow and innovate.

Three different models of corporate-startup collaboration and their effects on the case companies' capabilities were examined by Steiber \& Alange (2019). They found out that collaboration with startups was found to positively affect the firms' business 
transformation.

As far as the reasons for companies to collaborate with startups and vice versa, a joint research study made by Imaginaik and Masschallenge (2016) revealed that 60 pct. of the organizations responded that one of the top two priorities was to "explore new technologies and/ or business models". The next highest priority was to "explore nascent industries" (26 pct.), also strongly suggesting a preference for early-stage interactions. Taken together, 67 pct. of companies voiced one (or both) of these early-lifecycle activities as a priority. These options handily beat out other priorities like "leverage new and/or faster routes to market", or "earn a financial return on (venture) investment", which were priorities for a mere $18 \mathrm{pct}$ and $10 \mathrm{pct}$, respectively.

In the startup point of view, most startups view corporate relationships as multi-faceted, and potentially leading to a variety of benefits over time. Some startups think that instead of trying to disrupt a whole industry, working with incumbents could help them gain access to markets faster than doing it by themselves, or learning from them could help lead to greater success, and mutual benefit, for both (Imaginaik and Masschallenge, 2016).

In Younis \& Desai survey (2019), most companies engage with startup to gain access to new technology (92 pct.), 56 pct. are trying to execute a pivot or transformation of their business, gain access to talent (46 pct.) and reach new customers (45 pct). These responses expanded what is written in the Introduction providing new reasoning of why the corporations engage with startups.

In the Oxford Research (2019), 70 pct. of the Nordic corporates collaborate with startups to explore/create innovative or specialized technologies, products, solutions and/or processes, while 58 pct. work with start-ups to access innovative business models and industry trends. In this same study, corporations were asked in which ways successful collaborations with startups have helped them. Startups helped them to either explore/create innovative or specialized technologies, products, solutions and/or processes (67 pct.) or access innovative business models and industry trends (52 pct.). Other key results from collaboration with startups include fostering an entrepreneurial mindset and/or skills among corporate employees (39 pct.) and enhancing the image/branding of the corporate ( 36 pct.).

As far as the reasons why companies collaborate with startups and vice versa, 
Table 1 shows the reasons on companies' side and in Table 2 the reasons on startups side. 
Table 1. reasons why corporations collaborate with startups

\begin{tabular}{|l|l|}
\hline \multicolumn{1}{|c|}{ Reason } & \multicolumn{1}{|c|}{ Authors } \\
\hline $\begin{array}{l}\text { Organizational innovation/business } \\
\text { transformation }\end{array}$ & $\begin{array}{l}\text {-Steiber (2020) } \\
\text {-Ghobril, Franklin, Gava, Libano, Silva and } \\
\text { Zinger (2019) } \\
\text {-Steiber and Alange (2019) } \\
\text {-Younis and Desai (2019) } \\
\text {-Oxford Research (2019) }\end{array}$ \\
\hline $\begin{array}{l}\text { Technological innovation/ new } \\
\text { technologies }\end{array}$ & $\begin{array}{l}\text {-Ghobril, Franklin, Gava, Libano, Silva and } \\
\text { Zinger (2019) } \\
\text {-Imaginaik and Masschallenge (2016) } \\
\text {-Younis and Desai (2019) } \\
\text {-Oxford Research (2019) }\end{array}$ \\
\hline $\begin{array}{l}\text { Explore new business model } \\
\text { Leverage new and/or faster routes to } \\
\text { market }\end{array}$ & $\begin{array}{l}\text {-Imaginaik and Masschallenge (2016) } \\
\text {-Oxford Research (2019) }\end{array}$ \\
\hline $\begin{array}{l}\text { Earn a financial return on (venture) } \\
\text { investment }\end{array}$ & $\begin{array}{l}\text { Imaginaik and Masschallenge (2016) } \\
\text { (World Economic Forum, 2018) }\end{array}$ \\
\hline Gain access to talent & Younis and Desai (2019) \\
\hline Reach new customers & Younis and Desai (2019) \\
\hline Enhancing the image/branding & Oxford Research (2019) \\
\hline $\begin{array}{l}\text { Grow their companies, improve their } \\
\text { competitive positions }\end{array}$ & (World Economic Forum, 2018) \\
\hline
\end{tabular}

Table 2. reasons why startups collaborate with corporations

\begin{tabular}{|l|l|}
\hline Gain access to markets & Imaginaik and Masschallenge, 2016 \\
\hline $\begin{array}{l}\text { To grow their companies, improve their } \\
\text { competitive positions and generate } \\
\text { revenue }\end{array}$ & World Economic Forum, 2018 \\
\hline Help led to greater success & Imaginaik and Masschallenge, 2016 \\
\hline
\end{tabular}

The most cited reasons on the corporation side are "Organizational innovation/business transformation" and "Technological innovation/ new technologies", meaning that corporations are looking for the innovations that the startup can bring.

\subsection{Types or models of Collaboration or Engagement}

A growing number of large companies now have dedicated programs to proactively create, and then manage relationships with startups. Variously referred to as innovation labs, incubators, or any of myriad other names, very few of these programs existed more than one to two years ago, and have now proliferated (Imaginaik and Masschallenge, 2016).

The common goal between organization and startup in any type or model of collaboration is to grow their companies, improve their competitive positions and generate revenue. 
Differences such as agility versus static processes, diverging work ethics and different levels of risk tolerance should be issues to consider when analyzing engagement proposals and their processes (World Economic Forum, 2018). Nevertheless, these issues can be mitigated or accommodated depending on model of collaboration proposed.

The term collaboration or engagement is generally defined as activity or activities encompassing a variety range of forms of interactions with startups. This section displays many common types or models of engagement or collaboration between a corporation and a startup.

\section{Corporate Venture Capital (CVC)}

It can fit in the dimension outside-in with equity participation. According to Bonzom and Netessine (2015), based on Forbes Global, over $60 \%$ of companies engage with startups through investment funds. This investment, rather than being sold, can be increased in particularly promising startups. For Mocker et al. (2015), the acquisition of startups is a logical extension of Corporate Venturing and can be a fast and impactful way to buy complementary technology or capabilities that solve specific business problems and/or enter new markets. Bonzom \& Netessini (2016) consider CVC as part of Investment model together with Loans, Debt and Microcredit.

\section{Mergers and Acquisition (M\&A)}

It is the situation where the organization seeks startups that have technology-based solutions to complement their line of products or services and enhance their development and access to other markets (Ghobril; Marcondes \& Benedetti, 2018, and Brigl et al., 2019). For Lucerga (2018), target company ceases to exist and differently from Ghobril et al. (2018), acquisition does not involve only technology-based solutions startups. This category also includes acqui-hires whereby an acquisition is done to acquire the team instead of the product or service (Bonzom \& Netessini, 2016). Well-known examples were the acquisitions of WhatsApp and Instagram by Facebook, Waze by Google, and LinkedIn by Microsoft (Bryan \& Hovenkamp, 2019).

\section{Partnering}

This is based on a long-term partnership where both sides benefit, i.e., organizations provide investments to startups in exchange for their technology demands worked on by them, where the startup wins (Ghobril; Marcondes \& Benedetti, 2018; Brigl et al., 2019). With startups increasingly driving disruptive innovations that are replacing technologies from large and traditional companies and also replacing their current business model, partnerships with these potential disruptors may be beneficial for both of them due to the difficulty of the large company getting disruptive innovations from themselves (Mocker, Bielli \& Haley, 2015; World Economic Forum, 2018).

\section{Accelerators and Corporate Incubators}

Both provide opportunities for corporations to support a small group of startups during a relatively short period of time (most of the time between three and six months). Typically, 
corporations offer founding help, space and mentoring during the construction and launch of their ventures, in exchange for equity (Kohler, 2016; Cohen et al., 2019; Brigl et al., 2019; Bonzom \& Netessini, 2016). For Lucerga (2018), incubation is a continuous intake startup support organization funded by the corporation, providing business development support. Brigl et al. (2019), on the other hand, state that incubators strengthen the core business and leverages external R\&D potential. Both of them originate from ideas developed within the organization, called inside out with equity participation.

\section{The Startup Program (or Platform)}

This is the inside-out, with no equity from the corporate, that seeks to encourage external innovation and to drive an existing corporate innovation. Its objective is to get startups to build their products using resources provided by the corporation to expand its market. Examples provide by Bonzom \& Netessini's study (2016) are AWS (Activate), Microsoft (BizSpark), BNP Paribas (Offre Starter), Enel (Enel for Start-ups), Google (Google for entrepreneurs) and Lloyds Bank (Business Account for Start-ups).

Based on several-years' empirical study of 30 large firms' collaboration with startups, Alange \& Steiber (2019) later validated and expanded Weiblen \& Chesbrough (2015) typology by introducing four additional models for corporate-startup collaboration. The end result became a typology including eight different models for corporate-startup collaboration, clustered into four main categories of corporate-startup collaboration models (Alange \& Steiber, 2019). The four categories and eight models are:

(1) Outside-In and Equity based: Corporate Venture and Corporate Acquisition

(2) Inside-Out and Equity based: Corporate Incubator and Internal Accelerator

(3) Outside-In and Non-Equity based: Co-creation and Co-location

(4) Inside-Out and Non-Equity based: Platforms and Startup Programs

Weiblen and Chesbrough framework (2015) considered two dimensions; the direction of the innovation flow (from the "outside-in" or from the "inside-out"), and if the large firm takes equity or not in the startup.

Other types of engagements that have emerged over time, to complement traditional ones, are now essential for startups to thrive. They are described below.

\section{Support Services}

These are relationships sponsored by large corporations to provide mentoring, training, legal, accounting and marketing to startups, using their own experts or through external consultants (100 open startups, 2017; Bonzom \& Netessine, 2016).

\section{Co-working spaces}

These are places where corporations and startups can work side by side (Mocker et al, 2015). Google Campus is a space for startups with connection programs and mentoring, mixing training with mentoring relationship and coworking. Another well-known example 
is Itaú's CUBO, where several companies and startups share the same space in search of innovation, learning and partnerships, developing ideas and relationships in a very similar to Google Campus and InovaBra of Bank Bradesco (100open startups, 2017)). America Movil (Telmex), Credit Agricole (Le village), Heineken (Orange Grove) and Bayer (the CoLaborator) are other examples (Bonzom \& Netessini, 2016).

Events

There are four different channels to reach out to startups - hackathons, competition, sponsorship, and conference (Bonzom \& Netessini, 2016). Startup competition is an innovation competition focused on particular corporate problems, targeting external sources of talent, and attracting startups (Lucerga, 2018). Example of contest is hackathons, consisting of a marathon in which several teams, with experts such as programmers and graphic designers, have an intense collaboration, with limited time, to develop a project that solves with innovation a challenge that a corporation has (Newton, 2015; Briscoe and Mulligan, 2014; Mocker et al., 2015). Hackathons are movements that foster the partnership of large companies and small groups in the creation of startups (100 open startups, 2017).

\section{Innovation lab/center}

Corporate facility supporting startups with early stages of conception and design. Convene teams of in-house innovators for rapid prototyping (Lucerga, 2018) and market testing of new products and services (Brigl et al., 2019).

\section{Contracting a pilot project}

It is another type of engagement where a company implements a pilot project from a startup to prove the viability of the project, having in mind a future supply contract (100 open startups, 2017; Younis \& Desai, 2019).

\section{Matchmaking and connections}

They are one way of relationship that provides networking and connections between startups and large companies that want to engage with them (100 open startups, 2017).

The table 3 displays all types of engagement/collaboration with the meaning and their respective references. 
Table 3. Types of engagements

\begin{tabular}{|c|c|c|}
\hline Type & Definition & Authors \\
\hline $\begin{array}{l}\text { Corporate Venture } \\
\text { Capital }(C V C)\end{array}$ & $\begin{array}{l}\text { Is a program of the incumbent } \\
\text { company that aims to invest in } \\
\text { startups to increase sales and } \\
\text { revenues and obtain an } \\
\text { attractive return on investment }\end{array}$ & $\begin{array}{l}\text { Bonzom and Netessine (2015); } \\
\text { Mocker et al. (2015); } \\
\text { (Grando, 2016) } \\
\text { Chesbrough (2015) }\end{array}$ \\
\hline $\begin{array}{l}\text { Mergers and } \\
\text { Acquisition }\end{array}$ & $\begin{array}{l}\text { the organization seeks startups } \\
\text { that have technology-based } \\
\text { solutions (or just solutions) to } \\
\text { complement their line of } \\
\text { products or services }\end{array}$ & $\begin{array}{l}\text { Brigl et al., 2019; } \\
\text { Lucerga (2018) } \\
\text { Ghobril et al. (2018). } \\
\text { (Bonzom and Netessini, 2016). } \\
\text { Chesbrough (2015) }\end{array}$ \\
\hline Partnering & $\begin{array}{l}\text { a long-term partnership where } \\
\text { both sides benefit }\end{array}$ & $\begin{array}{l}\text { Ghobril; Marcondes \& Benedetti, } \\
\text { 2018; } \\
\text { Brigl et al., } 2019 \\
\text { Mocker, Bielli \& Haley, 2015; } \\
\text { World Economic Forum, } 2018\end{array}$ \\
\hline $\begin{array}{l}\text { Accelerators and } \\
\text { Corporate } \\
\text { Incubators }\end{array}$ & $\begin{array}{l}\text { corporations support a small } \\
\text { group of startups, offering } \\
\text { founding help, space and } \\
\text { mentoring in exchange for } \\
\text { equity for a relatively short } \\
\text { period of time }\end{array}$ & $\begin{array}{l}\text { Kohler, 2016; } \\
\text { Cohen et al., 2019; } \\
\text { Brigl et al., 2019; } \\
\text { Bonzom and Netessini, } 2016 \\
\text { Lucerga (2018) } \\
\text { Brigl et al. (2019) } \\
\text { Chesbrough (2015) }\end{array}$ \\
\hline $\begin{array}{lr}\text { The } & \text { Startup } \\
\text { Program } & \text { (or } \\
\text { Platform) } & \end{array}$ & $\begin{array}{l}\text { get startups to build their } \\
\text { products using resources } \\
\text { provided by the corporation to } \\
\text { expand its market }\end{array}$ & $\begin{array}{l}\text { Bonzom and Netessini, } 2016 \\
\text { Alange and Steiber (2019) } \\
\text { Chesbrough (2015) }\end{array}$ \\
\hline Support Services & $\begin{array}{l}\text { sponsored by large } \\
\text { corporations to provide } \\
\text { mentoring, training, legal, } \\
\text { accounting and marketing to } \\
\text { startups, using their own } \\
\text { experts or through external } \\
\text { consultants }\end{array}$ & $\begin{array}{l}100 \text { open startups, } 2017 \\
\text { Bonzom and Netessine, } 2016\end{array}$ \\
\hline Co-working spaces & $\begin{array}{l}\text { Places where corporations and } \\
\text { startups can work side by side }\end{array}$ & $\begin{array}{l}\text { Mocker et al, } 2015 \\
\text { 100open startups, } 2017 \\
\text { Bonzom and Netessini, } 2016\end{array}$ \\
\hline Events & $\begin{array}{l}\text { Like hackathons, competition, } \\
\text { sponsorship, and conferences }\end{array}$ & $\begin{array}{l}\text { Bonzom and Netessini, } 2016 \\
\text { Lucerga, } 2018\end{array}$ \\
\hline
\end{tabular}




\begin{tabular}{|l|l|l|}
\hline & & $\begin{array}{l}\text { Newton, 2015; } \\
\text { Briscoe and Mulligan, 2014; } \\
\text { Mocker et al., 2015 } \\
100 \text { open startups, 2017 }\end{array}$ \\
\hline $\begin{array}{l}\text { Innovation } \\
\text { lab/center }\end{array}$ & $\begin{array}{l}\text { Corporate facility supporting } \\
\text { startups with early stages of } \\
\text { conception and design, for } \\
\text { rapid prototyping and market } \\
\text { testing of new products and } \\
\text { services }\end{array}$ & $\begin{array}{l}\text { Lucerga, 2018 } \\
\text { Brigl et al., 2019 }\end{array}$ \\
\hline $\begin{array}{l}\text { Contracting a pilot } \\
\text { project }\end{array}$ & $\begin{array}{l}\text { a company implements a pilot } \\
\text { project from a startup to prove } \\
\text { the viability of the project, } \\
\text { having in mind a future supply } \\
\text { contract }\end{array}$ & Younis and Desai, 2019; \\
\hline $\begin{array}{l}\text { Matchmaking and } \\
\text { connections }\end{array}$ & $\begin{array}{l}\text { one way of relationship that } \\
\text { provides networking and } \\
\text { connections between startups } \\
\text { and large companies that want } \\
\text { to engage with them }\end{array}$ & \\
\hline
\end{tabular}

\section{Methodology}

As an exploratory empirical study, the goal of this paper is to investigate evidence about the dynamics of corporate startup collaboration. This method (Mollick, 2014; Cornelius, 2006) is appropriate for this evolving topic, and this resulting data can serve as a useful base for developing a body of knowledge and also as a basis, for those companies that are not yet engaged, to start engaging and/or create a line of innovation and engagement strategy.

The data regarding engagements was extracted from the e-book "100 Open startups" (2017) and amplified this sample with 2019 edition of magazine "Exame" with the list of 500 Melhores e Maiores (Best and Biggest companies).

We started verifying the evolution, from 2017 to 2019, of the existing engagements that Brazilian corporations had with startups, where 111 companies had engagements with startups back in 2017, thirteen were discontinued totaling 98 companies in 2019.

In order to increase this sample, we used the 2019 edition of magazine "Exame". We run through this list till position top 65th company. The revenue of these top 65 companies represents $54 \%$ of the 500 Melhores e Maiores total revenue. Eighteen of them were already in our initial database of 98 companies, eighteen had no single type of engagement with startups and only 29 (with engagements) were added to our sample, totaling 127 companies 
The search for companies, programs and relationships followed 3 steps, which were repeated for each company of the database:

a) look into search tools like Google, LinkedIn, Facebook, with company name followed by "startup" e.g., "Accenture Startup" to find some news, like articles in newspapers, magazines, and blogs about possible engagements. If nothing was found, other words were added after the company name, such as "innovation" or "digital transformation";

b) another way was to look into the company's institutional site for programs and relationships it has with startups. As an example, see figure 2:

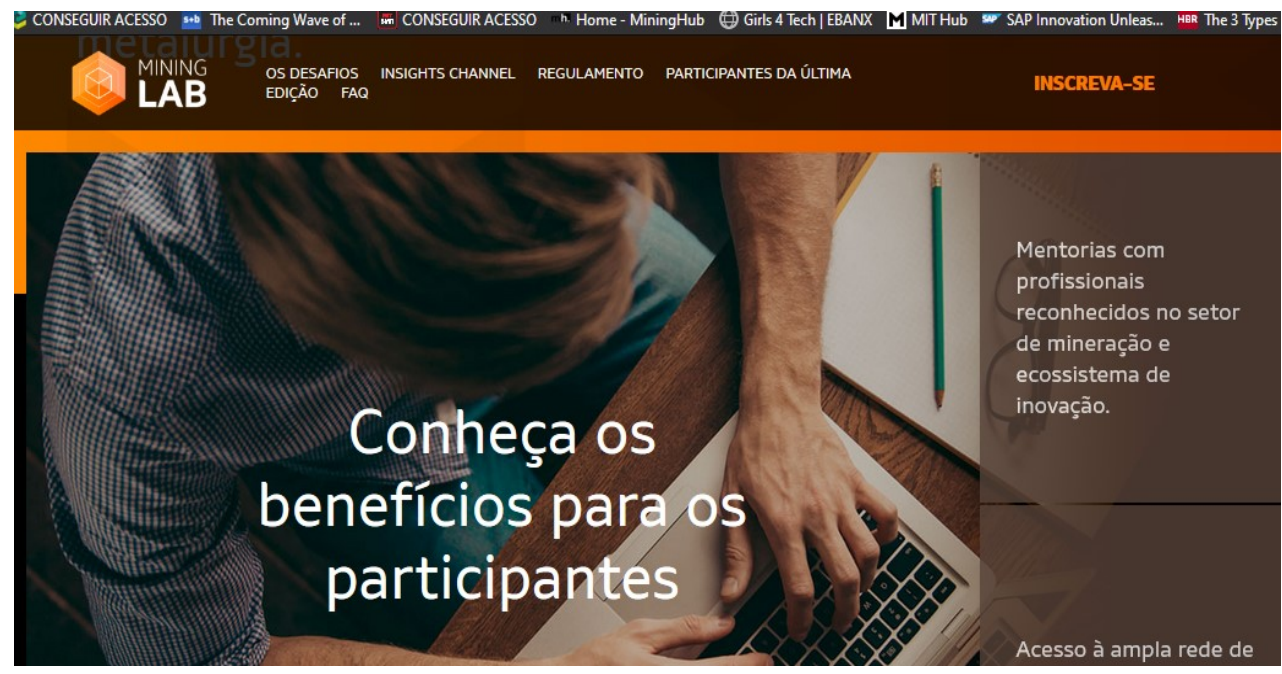

Figure 2. Benefits for the participants of Mining Lab of the company Nexa (access on 10/25/2019 http://www.mininglab.com.br/pt/)

After searching for the company "Nexa startup", the site Mining Lab was found, in the tab "benefits for participants" it was possible to see the various types of engagement: expert mentoring, project development investment, in line with the "pilot project development resources" collaboration.

c) once the programs are found, they were connected with the respective relationships and start the process again.

Figure 3 displays the research cycle used. 


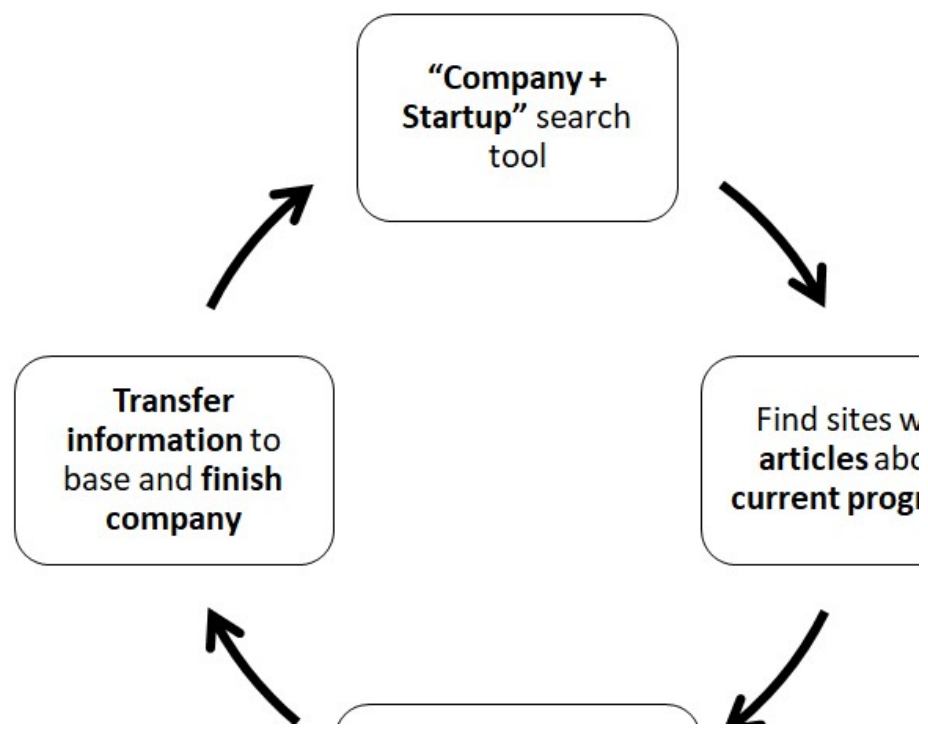

Figure 3. Research cycle

In our study, the programs are the means by which a company collaborates with the startups and are classified in three types:

- Own program: Corporations like Itaú, Bradesco, Votorantim and Natura created their own entrepreneurial hub (named Cubo, Inovabra, Votorantim Hub and Natura Startups respectively) to connect in the same space entrepreneurs, investors, and startups in search of new business opportunities. For a startup to be a resident or a member of a hub, it must offer a scalable solution that has already been tested by customers or in process of testing.

- Shared Programs: Several companies sponsor a program that is fitted to specific startups that would probably evolve to partnership. These programs are usually run by another non-profit or profit organization (Program Startup-Indústria has sponsors from $3 \mathrm{M}$ and Natura).

- Program / Company: acting in two ways, like a corporate accelerator that helps companies create open innovation programs with startups and internal entrepreneurship actions (like Liga Ventures and ACE) and/or as a platform connecting companies and startups (100 Open Startups).

Regarding the reasons why corporations engage with startups and vice versa, we sent a qualitative questionnaire with open questions via Google Forms to 80 corporations and 130 startups and received only 7 and 13 responses respectively from them.

\section{Results and Discussion}

We divided this section in 3 parts - results from the database of 100 Open Startups, results expanded with the 2019 edition of magazine "Exame" and the qualitative responses from corporations and startups.

The types or models of Collaboration or Engagement and the reasons why companies collaborate with startups and vice-versa, as shown in the Literature review section, will be 


\section{Macrothink}

used in analyzing and discussing the results.

\subsection{Results from the database of 100 Open Startups}

There were 111 companies with 300 engagements with startups through 129 programs in this database back in 2017. Thirteen companies were discontinued along with 33 programs and 44 engagements. On the opposite direction, 94 new programs and 294 new engagements were added as can be seen in the Table 4. There was a huge increase in programs and engagements ( $47 \%$ and $83 \%$ respectively) despite the decrease in number of companies.

Table 4. Evolution from 2017 to 2019

\begin{tabular}{|l|c|c|c|c|}
\hline & 2017 & Discontinued & New & 2019 \\
\hline Company & 111 & 13 & - & 98 \\
\hline Program & 129 & 33 & 94 & 190 \\
\hline Engagement & 300 & 44 & 294 & 550 \\
\hline
\end{tabular}

This position in 2019 can be broken down by industry sector (see 


\section{Macrothink

Table 5). No surprise the Technology and Innovation is the leading sector in number of companies / programs / engagements. High tech equipment industry and Communication fit into this sector. This is followed by Financial Service, considering the activities performed by the banking system, emergence of fintech, insurance services and real estate services, and Energy because these companies are searching new alternative and clean sources, biofuel, and renewable energy. These five sectors represent $48 \%$ of companies of our sample, $51 \%$ of the programs and $49 \%$ of engagements.

No doubt, the driving forces behind these three sectors boosted the search for innovation and collaboration strategy and explain part of the dynamics and the growth of CSC. 
Table 5. Break down by industry sector 2021, Vol. 13, No. 2

\begin{tabular}{|l|c|c|c|l|l|}
\hline & Company & Program & Engagement & $\begin{array}{l}\text { New } \\
\text { programs }\end{array}$ & $\begin{array}{l}\text { New } \\
\text { engagem. }\end{array}$ \\
\hline $\begin{array}{l}\text { Technology } \\
\text { innovation }\end{array}$ & 21 & 42 & 115 & 21 & 62 \\
\hline Financial Services & 12 & 26 & 74 & 14 & 57 \\
\hline Energy & 6 & 14 & 39 & 8 & 22 \\
\hline Telecommunication & 4 & 10 & 29 & 6 & 19 \\
\hline Automakers & 4 & 5 & 13 & 1 & 4 \\
\hline Others & 51 & 93 & 280 & 44 & 130 \\
\hline Total & 98 & 190 & 550 & 94 & 294 \\
\hline
\end{tabular}

Looking to the engagements (total of 9 types), the top seven types represent $78 \%$ of the total. See figure 4.

Engagements being matchmaking and mentoring the top two of the lists followed by pilot project contracting, coworking and corporate venture.

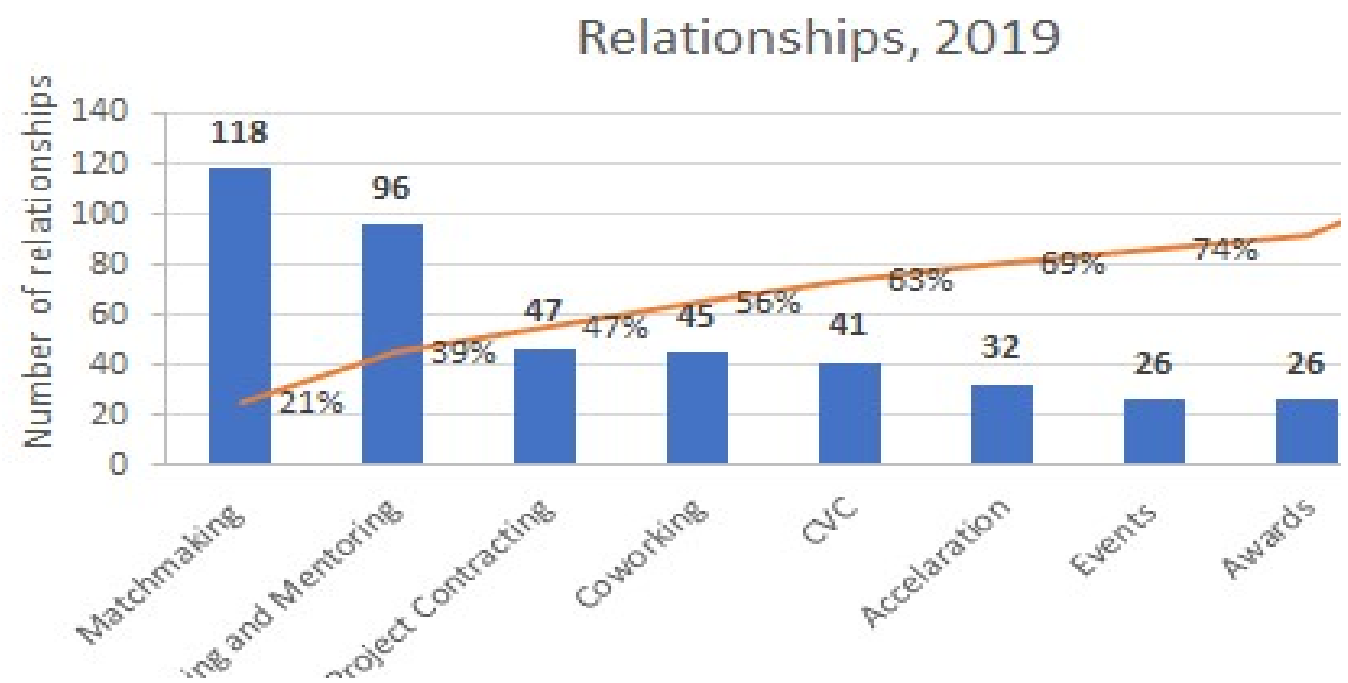

Figure 4. Types of engagement / relationships

\subsection{Results expanded with the 2019 edition of magazine "Exame"}

This sample of the 98 companies was expanded with the 2019 edition of magazine "Exame" and resulted in addition of 29 companies, 40 programs and 108 engagements 
making the sample bigger. It can be seen on Table 6 .

Table 6. Position in 2019

\begin{tabular}{|l|c|c|c|}
\hline & 2019 & Additions & $\begin{array}{l}2019 \text { plus } \\
\text { Exame magazine }\end{array}$ \\
\hline Company & 98 & 29 & 127 \\
\hline Program & 190 & 40 & 230 \\
\hline Engagement & 550 & 108 & 658 \\
\hline
\end{tabular}

This sample post Exame Magazine was also broken down by industry sector (see Table 7). The top 3 sectors in the previous breakdown continue the same - Technology and Innovation, Financial and Energy. Retail sector did not stand out in the previous database (there were only three companies in 100 Open Startup database) and shows now as the $4^{\text {th }}$ most important sector in companies, programs, and engagements with startups. There is a growing interest by them in exploring new ways of digital trade marketing and distribution and in new platforms such as omnichannels in order to face fierce competition and cut cost. Energy and Retail were the sectors that had the newest companies ( 8 and 5 respectively), programs (9 and 11) and engagements (36 and 30).

These findings reinforce what was said earlier in table 4, of these sectors searching for innovation and collaboration strategy and their growth. Important to note the appearance in two years time of Retail sector with its driving forces pushing for new ways of doing business.

Two sectors that did not appear in this research and should be part due to Brazil relevance are Oil and Nature Gas and Heath Care. Oil and Nature Gas contemplating fossil fuel market and natural gas and Health Care with the areas of molecular biology, medical biotechnology, pharmacology, and medical devices.

In all the articles researched, the authors managed to find only one study that made an overview by industry (Bonzom \& Netessine, 2016). They focus on industries where at least 10 companies were engaging with startups. Some industries are more focused on one channel, such as the corporate venture arm for the pharmaceuticals industry (13 out of 17 companies), whereas the telecommunication services industry has been using a wide range of channels to engage with startups - 19 out of 23 have CVC, 11 have accelerators and incubators and 7 have organized competitions. Regarding major banks, CVC and competition are the favorite collaborations for 10 out of 20 , followed by accelerators and incubators for 8 of them. Finally, in the insurance industry, Corporate venture arms is the channel used by 10 out of 17 , followed by startup competitions (4 out of 17), and Startup Programs for 3 of them.

These results contrast with our study where the only industry sector similar is the 
bank/financial services. Pharmaceutical and telecommunication services do not even appear in our radar.

Table 7. Break down by industry sector post Exame Magazine

\begin{tabular}{|c|c|c|c|c|c|c|}
\hline & $\begin{array}{l}\text { Compan } \\
\mathrm{y}\end{array}$ & $\begin{array}{l}\text { New } \\
\text { Companie } \\
\text { S }\end{array}$ & $\begin{array}{l}\text { Progra } \\
\mathrm{m}\end{array}$ & $\begin{array}{l}\text { New } \\
\text { program } \\
\text { S }\end{array}$ & $\begin{array}{l}\text { Engageme } \\
\mathrm{nt}\end{array}$ & $\begin{array}{l}\text { New } \\
\text { engagem } \\
\text {. }\end{array}$ \\
\hline $\begin{array}{l}\text { Technology and } \\
\text { Innovation }\end{array}$ & 21 & 0 & 42 & 0 & 115 & 0 \\
\hline Financial Services & 13 & 0 & 26 & 0 & 74 & 0 \\
\hline Energy & 14 & 8 & 23 & 9 & 75 & 36 \\
\hline Retail & 8 & 5 & 13 & 11 & 32 & 30 \\
\hline Automotive & 6 & 2 & 7 & 2 & 15 & 2 \\
\hline $\begin{array}{l}\text { Telecommunicatio } \\
\mathrm{n}\end{array}$ & 5 & 1 & 12 & 2 & 33 & 4 \\
\hline Others & 60 & 13 & 107 & 16 & 314 & 36 \\
\hline Total & 127 & 29 & 230 & 40 & 658 & 108 \\
\hline
\end{tabular}

Focusing now on engagements post Exame Magazine, the types of engagements follow the same pattern as of the previous database. The top seven types are the same compared with the previous database and continue representing $78 \%$ of the total engagements. Surprisingly, Matchmaking continues as the first collaboration and this type is not even mentioned as such in the international articles researched. This list is followed by Mentoring/training (support services), pilot project contracting, coworking and corporate venture (see figure 5). The first four types are more adherent to the concept of collaboration between corporation and startup. 


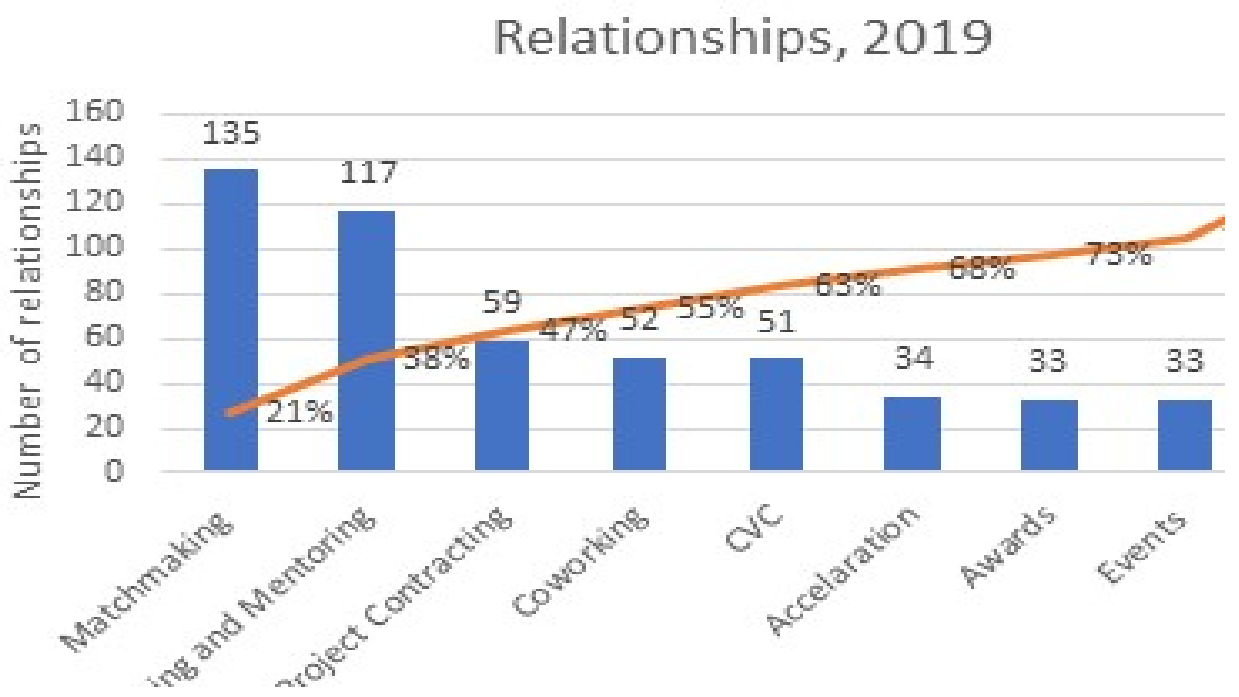

Figure 5. Types of relationship post Exame Magazine database

Comparing the results of relationships of the two databases, the biggest increases were in pilot project contracting $(25,5 \%)$, corporate venture (CVC) $(24,3 \%)$, awards $(26,9 \%)$ and events $(26,9 \%)$. See Table 8 .

Table 8. Two databases compared

\begin{tabular}{|l|c|c|c|}
\hline $\begin{array}{l}\text { Types of relationship/ } \\
\text { engagement }\end{array}$ & $\begin{array}{l}100 \\
\text { Startup database }\end{array}$ & $\begin{array}{l}\text { Post Exame } \\
\text { Magazine database }\end{array}$ & \begin{tabular}{l}
$\%$ variance \\
\hline Matchmaking
\end{tabular} 118 \\
\hline Training and mentoring & 96 & 135 & 14,4 \\
\hline Pilot Project contracting & 47 & 117 & 21,8 \\
\hline Coworking & 45 & 59 & 25,5 \\
\hline CVC & 41 & 52 & 15,5 \\
\hline Acceleration & 32 & 51 & 24,3 \\
\hline Awards & 26 & 34 & 6,2 \\
\hline Events & 26 & 33 & 26,9 \\
\hline Others & 119 & 33 & 26,9 \\
\hline Total & 550 & 144 & 21 \\
\hline
\end{tabular}

However, the above results contrast from the commom models of collaboration found in the literature, such as $\mathrm{CVC}$, incubation, partnering, startup platform. Bonzom and Netessine (2016), using the ranking of Forbes Global 500 has found that 262 companies are working with startups in one way or another. That's 52.4 pct. The most common type 
of collaboration is through Corporate Venture Capital in 62.6 pct. of cases, following by startup competition (29.0 pct.) and setting up accelerators and incubators (24.4 pct.). This is a viable comparison given the magnitude of both samples, 127 companies in the Brazilian sample and 262 in international sample (Forbes).

What do these results tell us? That the dynamics of CSC in Brazil is in a different stage compared to abroad. Key to a successful collaboration is to see just as partnership rather than an one-off transaction where both sides can learn and grow in this process. This is not the case of models such as CVC or M\&A where they are dominant models of collaboration abroad. In Brazil, we see dominance of Matchmaking, Training and Mentoring and Pilot Project Contracting, that are more adherent to the concept of collaboration. These first two relationships, which hold 38\% of engagements, require less commitment from both parties with both sides seeking to initiate their engagement programs, and can be perceived as being a more primary type of collaboration.

As far as programs are concerned, our survey shows that Own Program is the top with 110 programs out of 230 (48pct.) followed by Program/Company with 75 (33 pct.) and Shared Program with 45 (20pct.) (see table 9). These results are in line with the literature, where startup program/platform (inside-out or outside-in) is a common traditional model. It is clear that companies prefer to create their own entrepreneurial hub to connect in the same space entrepreneurs, investors, and startups. Nevertheless, these three types of programs reinforce the concept that companies and startups are not alone and have to be part of an ecosystem working with other parties.

Table 9. Types of program

\begin{tabular}{|l|l|l|l|}
\hline Types of program & & Quantity & $\%$ \\
\hline Own program & & 110 & 48 \\
\hline Shared program & & 45 & 20 \\
\hline Program / Company & & 75 & 33 \\
\hline Total & & 230 & 100 \\
\hline
\end{tabular}

The programs and industry sector are detailed by types of program (Table 10). The ranking of each of the program types follows the same ranking of industry sector, being T\&I the top with 42 programs followed by Financial with 26 and Energy with 23. It is good to hear that these sectors are involving other parties of the ecosystem. 
Table 10. Programs and industry sector

\begin{tabular}{|l|l|l|l|l|}
\hline Sector & $\begin{array}{l}\text { Own } \\
\text { program }\end{array}$ & $\begin{array}{l}\text { Shared } \\
\text { program }\end{array}$ & $\begin{array}{l}\text { Program / } \\
\text { Company }\end{array}$ & Total \\
\hline T\&I & 21 & 7 & 14 & 42 \\
\hline Financial Services & 10 & 4 & 12 & 26 \\
\hline Energy & 12 & 3 & 8 & 23 \\
\hline Retail & 4 & 3 & 5 & 12 \\
\hline Automotive & 1 & 1 & 5 & 7 \\
\hline Telecommunication & 6 & 2 & 4 & 12 \\
\hline Others & 56 & 25 & 27 & 108 \\
\hline Total & 110 & 45 & 75 & 230 \\
\hline
\end{tabular}

4.3 Reasons for corporations and startups engaging with each other, failures, and challenges

We have asked companies and startups the reasons for engaging with each other and the disadvantages for doing so. The reasons on the corporate side are displayed below:

Work with people with outside "the box" thinking; create and promote an innovation environment and digital transformation inside the organization, appropriating innovation culture inside the organization; have freedom to make mistakes in the creation/development process; have flexibility to form strategic partnerships to meet the final consumers market; become eligible to challenges exposed to startups community, thus following the market opportunities; capillarity, knowledge of small business.

These reasons presented are very much in line with the literature, such as explore nascent industries or market opportunities, access to new technology/innovation, new customers, and talent, ie, people that think outside the box.

Some reasons or benefits listed in WEF paper (2018) were not present in our survey customer focus, new revenue streams and business lines.

The reasons on the startup side are displayed below:

Favorable environment to interact with other companies and gain visibility; higher status; success case; get knowledge and open doors to the market; positive reputation to be associated with relevant companies/brands, besides validating the quality of our products and services; develop and test our solutions on a bigger base of consumers; increase visibility and credibility in our clients; strengthening the brand and expanding customer base; win / win situation for both parties

These reasons are also similar to literature, such as, gain access to market/bigger base of 
customers and view corporations as established marketing channels/increasing visibility for the brand and win/win situation/learning from both parties. Some reasons or benefits listed in WEF paper (2018) were not present in our survey - Success story for future sales, riskless internationalization, attractive retail channel and access to proprietary assets,

However, there are some few disadvantages for engaging that corporations mentioned:

- High mortality rate of the startups

- Lack of processes in the startups

- Few cases to validate the performance or success of the products and services

- Risk of non-continuity / business interruption

- Low business volume

- Tradeoff between the efforts and resources put into startups versus financial results obtained can be no beneficial to corporation.

In this same line, Brigl et al. (2019) listed various reasons why this partnership fails on both sides. The top three reasons on corporate side were no mutual recognition or cooperation on an equal footing, no clear steering and governance and hard and lengthy decision making. On the startup side hard and lengthy decision making and no ability and willingness to move at same speed.

On the challenges side when collaboration with startups, one issue is the risk aversion that the corporates have in investing their resources and time in risky projects that may not succeed in the end. 45 pct. point out that this is an obstacle to their engagement with startups. Another issue that corporates face is bureaucratic obstacles (58 pct.), where procurement is a common challenge. If the collaboration results in developing a technology that may be deployed to other lines of businesses, the procurement department gets involved. They represent gateways that can sometimes be difficult to overcome, as they follow strict corporate processes (Oxford Research, 2019).

WEF Guide (2018) distinguishes the challenges for startups and corporates. The most common for startups are duration of sales cycle, client's protective middle management, insufficient resources, chasm between proof of concept and real projects, trust without references and top-down approach. For corporates, the most cited were not-invented-here problem, managerial support, siloed approach, understanding change and innovative organization.

\section{Conclusion}

In the ever-changing business landscape, companies across industries have been challenged by startups, mainly on Technology and Innovation, Financial, Energy and Retail in our study. The startup phenomenon is also affecting banking, pharmaceutical, logistics and telecommunication in other parts of the world. To the world, established corporations seem to be adapting slowly. This report explores the extent to which that is true and uncovers ways corporations can engage startups for business excellence. 
Creating a successful startup is a balancing act amongst many variables simultaneously often amidst environments of extreme uncertainty and volatility. One of the most important balancing acts is between The Inner Dimensions Customer (Relationship, Product, Team, Finance and Legal) and The Outer Dimensions (Users, Customers, Product Usage and Revenue) of a startup. Startup Science discovered that the primary reason startups fail is that their Inner Dimensions get ahead of their Outer Dimensions (Startup Genome, 2019). This is one strong reason for startups to engage with corporation and gain experience in scaling and sustaining the business.

The results of this exploratory study suggest that a number of findings should be of interest to entrepreneurship scholars to understand the dynamics of CSC.

First, without doubt, the driving forces behind Technology and Innovation, Financial Services, Energy and Retail sectors boosted the search for innovation and collaboration strategy and the growth of CSC in two years time.

Second, the dynamics of CSC in Brazil is in a different stage compared to abroad. In Brazil, we see dominance of Matchmaking, Training and Mentoring and Pilot Project Contracting types. We see them as partnership between corporation and startup, where both sides can learn and grow in this process, rather than an one-off transaction. This is the case of models such as CVC or M\&A, dominant models of collaboration abroad.

Third, reasons on collaboration reinforce above concept with win/win situation, learning from both parties by creating and promoting an innovation environment and appropriating innovation culture inside the organization.

Fourth, the three types of programs - Own program, Shared program and Program and Company - reinforce the concept that companies and startups are not alone and have to be part of an ecosystem working with other parties.

Together, these findings suggest that there is substantial value in further studying the dynamics of CSC, since it sheds light on a variety of subjects of interest to academics, businessman and entrepreneur, when it comes to reduce the reasons why the partnership fails and overcome the challenges.

Corporations can use the results of this research to explore ways to engage with startups and to looking to benchmark their practices. They and startups can also use these results to outline a strategy for innovation and engagement to improve their performances.

Startups everywhere are experimenting with new business models to reinvent traditional industries - or create entirely new ones. On the corporation side, the companies can also build on the key relationships, mentioned in this research, to create programs that aim to achieve the same goals.

A limitation of this study was the small number of responses from companies and startups. A bigger number would provide a more in-depth insights and help to outline the strategy for innovation and engagement as mentioned above. Suggestion for a future research is to have personal interviews with the executives responsible of the leading industry sectors (in 
number of companies / programs / engagements) to understand their behavior and motivations.

\section{References}

100 open startups. (2017). Como grandes empresas e startups se relacionam. Retrieved from $<$ https://www.openstartups.net/br-pt/ebooks/>

100 open startups. (2020). Insights. Retrieved from $<$ https://www.openstartups.net/site/ranking/insights-2020.html $>$

Alange, S., \& Steiber, A. (2019). Working with Startups for Corporate Innovation: Typology of Eight Operational Models, submitted to Business Horizon, Bloomington, Indiana

Blank, S. (2010). Why Startups Are Agile and Opportunistic-Pivoting the Business Model. Retrieved from $<$ https://steveblank.com/2010/04/12/why-startups-are-agile-and-opportunistic-\%E2\%80\% 93-pivoting-the-business-model/>

Brigl, M., Gross-Selbeck, S., Dehnert, N., Schmieg, F., \& Simon, S. (2019). After the Honeymoon Ends: Making Corporate-Startup Relationships Work. Boston Consulting Group. Retrieved from $<$ https://www.bcg.com/de-at/publications/2019/corporate-startup-relationships-work-afterhoneymoon-ends.aspx>

Bonzom, A., \& Netessine, S. (2016). \#500corporations: How do the world's biggest companies deal with the startup revolution? Technical report, 500 Startups and INSEAD.

Briscoe, G., \& Mulligan, C. (2014). Digital innovation: the hackathon phenomenon. Retrieved from $<$ https://www.semanticscholar.org/paper/Digital-Innovation\%3A-The-Hackathon-Phenom enon-Briscoe/cb8e44ec1bcd6062e5fccafb6837030be334731d>.

Bryan, K., \& Hovenkamp, E. (2019). Startup acquisitions, error costs, and antitrust policy. University of Chicago Law Review, 1-24.

Charles, A. (2016). Why companies must innovate or die. University of Bristol faculty of engineering. $\quad$ Retrieved from $<$ https://elvinos.uk/app/uploads/2017/08/WhyCompaniesMustInnovateAC.pdf $>$.

Chesbrough, H., Vanhaverbeke, W., \& West, J. (2006). Open Innovation: Researching a New Paradigm, US, Oxford University Press

Christensen, C. (1997). The Innovator's Dilemma: When new technologies cause great firms to fail. Boston, MA, Harvard Business School Press.

Christensen, C., Bartman, T., \& Van Bever, D. (2016). The hard truth about business model innovation. MIT Sloan Management Review, 58 (1).

Christensen, C., Raynor, M., \& McDonald, R. (2015). What is disruptive innovation. 
Harvard Business Review. Dec: 44-53.

Cohen, S., Fehder, D., Hochberg, Y., \& Murray, F. (2019). The design of startup accelerators. Research Policy, 48, 1781-1797. https://doi.org/10.1016/j.respol.2019.04.003

Cornelius, B. (2006). Entrepreneurial studies: the dynamic research front of a developing social science. Entrepreneurship Theory and Practice, 375-397. https://doi.org/10.1111/j.1540-6520.2006.00125.x

Drori, I., \& Wright, M. (2018). Accelerators: Characteristics, Trends and the New Entrepreneurial Ecosystem. In: Wright and Drori, (Eds), Accelerators. Successful Venture and Growth. Cheltenham, UK and Northampton, USA, E.E. Elgar, 1-20. ttps://doi.org/10.4337/9781786434098.00005

Exame, 2017. Melhores e maiores: as 1000 maiores empresas do Brasil. Editora Abril, Aug.

Exame, 2019. Melhores e maiores: as 1000 maiores empresas do Brasil. Editora Abril, Sep.

Grando, N. (2016). Beyond corporate venture capital: new ways corporations can engage with startups. Paper presented to the Administration Department of University of S Paulo USP, as a requirement for the Economics of Industrial Innovation course. Retrieved from: $<$ https://www.researchgate.net/publication/321921430_Beyond_corporate_venture_capital _new_ways_corporations_can_engage_with_startups $>$

Ghobri, L A. N., Franklin, M. A., Gava, F. A. M., Libano, M. A. B., Silva, M. N., \& Zinger, R. (2019). Cooperação Entre Corporações E Startups Em Programas De Corporate Venture, Facef Pesquisa: Desenvolvimento e Gestão, 22, (3)

Ghobril, A. N., Marcondes, R.C., \& Benedetti, M. H. (2018). Inovação Por Meio Da Integração Entre Corporações, Icts E Startups. 1o. Fórum De Liberdade Econômica. São Paulo.

Hogenhuis, B., Van den Hende, E., \& Hultink, E.J. (2017). Unlocking the Innovation Potential in Large Firms through Timely and Meaningful Interactions with Young Ventures. International Journal of Innovation Management, 21 (1). https://doi.org/10.1142/S1363919617500098

Imaginaik and Masschallenge. (2016). The state of startup / corporate collaboration. A Joint Study.

Kohler, T. (2016). Corporate accelerators: building bridges between corporations and startups. Business Horizons; 59, 347-357. https://doi.org/10.1016/j.bushor.2016.01.008

Linna Jr., D. (2016). What we know and need to know about legal startups; South Carolina Law Review; 1 (67), 389-417.

Lucerga, R. J. V. (2018). Open innovation strategy: a framework for corporate-startup collaboration. Master Of Science Dissertation In Management of Technology at The 
Massachusetts Institute Of Technology

Mocker, V., Bielli, S., \&Haley, C. (2015). Winning together: a guide to successful corporate-startup collaborations. Nesta. London.

Mollick, E. (2014). The dynamics of crowdfunding: An exploratory study. Journal of Business Venturing, 29, 1-16. https://doi.org/10.1016/j.jbusvent.2013.06.005

Newton, R. (2015). The hackathon enters the corporate mainstream. Financial Times. Feb.

Oxford Reserch. (2019). Corporate-startup collaboration report. Retrieved from $<$ https://www.nordicinnovation.org/2019/corporate-startup-collaboration-report>

Pénin, J., Hussler, C., \& Burger-Helmchen, T. (2011). New Shapes and New Stakes, a Portrait of Open Innovation as a Promising Phenomenon. Journal of Innovation Economics and Management. 7 (1), 11-29. https://doi.org/10.3917/jie.007.0011

Prashantham, S., \& Kumar, K. (2019). Engaging with startups: MNC perspectives. IIMB Management Review.

Ries, E. (2012). The lean startup: how constant innovation creates radically successful businesses. Penguin Books, US.

Salles, D. G. (2018). Grandes corporações e startups: Relações de inovação aberta ao Mercado Brasileiro. Master Dissertation. Faculdade de Economia e Administração. São Paulo University, 128 p.

Startup Genome. (2019). Global Startup Ecosystem Report.

Steiber, A. (2020) Corporate-startup Collaboration: Its Diffusion to and within the Firm. Triple Helix Journal, 1-27 doi:10.1163/21971927-bja10005

Steiber A., \& Alange S., (2019). Corporate-startup collaboration: effects on large firms' business transformation. European Journal of Innovation Management, 1460-1060.

Thieme, K. (2017). The Strategic Use of Corporate-Startup Engagement. Master Dissertation, Delft University of Technology. Retrieved from: $<$ https://repository.tudelft.nl/islandora/object/uuid\%3A0a933f8a-dc6c-4818-864a-8602593 a2bf5?collection=education $>$

Younis, Z., \& Desai, A. (2019). Unlocking Innovation Through Startup Engagement: Best Practices from Leading Global Corporations. 500 STARTUPS.

Yu, D., \& Hang, C. A. (2010). Reflective review of disruptive innovation theory. International Journal of Management Reviews. 12, 435-452. https://doi.org/10.1111/j.1468-2370.2009.00272.x

Weiblen, T., \& Chesbrough, H. (2015). Engaging with startups to enhance corporate innovation. California Management Review. 572, 66-90.

World Economic Forum, 2018. Collaboration between Start-ups and Corporates. A Practical Guide for Mutual Understanding 